\title{
Not lost in translation: Managerial career narratives and the construction of protean identities
}

Carola Wolf

\begin{abstract}
How can managers remain in charge of their own careers based on personal values and motivations, rather than surrendering to the vulnerabilities of modern day corporate bureaucracies? This question represents a core issue for managers whose careers have been significantly affected by changing business environments, new organizational forms and the related changes of work organization in modern day corporations. Managers can no longer rely on the traditional linear models of organizational careers. It is increasingly demanded that they be more flexible and direct their own careers, which is captured in new career concepts, such as the 'protean career'. Drawing on narrative identity theory, this study sets out to investigate how managers construct a protean identity and how specific narrative practices support individuals in shaping, implementing and defending this identity. The life stories of 29 individuals are analyzed, all of whom have experienced significant career changes. Based on these stories, four core narrative building blocks at the heart of protean identity construction and related narrative practices are identified, including (1) the discovery of conflicting expectations, (2) the exploration of one's own values and capabilities, (3) the commitment to one's own path and (4) defending that path.
\end{abstract}

\section{Keywords}

life story, management careers, managerial work, narrative identity, protean career 


\section{Introduction}

"I think the older I get, the more I realize that when I was young I always thought of a career as a script. So if I am not doing this, this, and this by 40, then I would have failed. And now I think about my lifespan and most probably I will be doing super-interesting work when I'm 50 and 60. [...]Now I have a career that I like. [...] Even if I have a hiccup on the grand scale of things in five years' time, it doesn't matter that much [...] whereas before I would have been stressed, I would have been worried. Now I am a little bit more chilled about the trajectory I take.” (Yvette, ${ }^{1}$ interview 29)

In dynamic business environments, organizations are dependent on managers at all hierarchical levels as drivers of strategic adaptability (e.g., Mollick, 2012; Wooldridge et al. 2008). However, many studies paint an especially vulnerable and dire picture of managerial professionals, such as middle managers, who face a number of pressures and insecurities with regard to their managerial roles and career development (Accenture, 2007; Hales, 2002; Hassard et al., 2012; Prins et al., 2015; Sims, 2003; Watson, 1994/2001). As a consequence, organizations risk losing key talent if professionals, for example, seek alternative ways to obtain a satisfying career and balanced work life (Biese, 2017; Feldman and Ng, 2007; Fraher and Gabriel, 2014).

To a large extent, this conflict boils down to major shifts of modern careers away from traditional organizational career patterns and the psychological contract at the heart of employee-employer relations towards new forms of career contracts (Arthur and Rousseau, 1996; Hall, 2002; Hassard et al., 2012; Sennett, 1998). The opening interview quote illustrates the challenges faced by professionals in managerial career tracks when living through the everyday conflicts and confusions entailed by such shifts from 'old' to 'new contracts' (Hall, 2002). We grow up with very specific ideas about what a (corporate) career 
typically looks like and how successful careers are typically expected to proceed (Gersick and Kram 2002; Giddens, 1991; Grote and Hall, 2013; Hall, 2002; Jackall, 1988/2010; Sennett, 1998; Super, 1990; Watson, 2009). While doing everything 'right' to follow these scripts, many managers realize that this does not necessarily reflect who they are or what they want and they miss a sense of fulfilment and satisfaction. They experience the clashing of the external pressures of success with their internal expectations and personal preferences $-\mathrm{a}$ conflict between ‘self-identity’ and ‘social-identity’ (Watson, 2009: 431; see also Hall, 2002; Ibarra and Barbulescu, 2010; Super, 1990).

The concept of a protean career promises that managers can take back control over their careers by self-directing their paths based on individual values and personal definitions of career success (Briscoe et al., 2006; Feldman and Ng, 2007; Hall, 1996, 2002):

"The protean career is a process which the person, not the organization, is managing. [...] The protean person's own personal career choices and search for self-fulfillment are the unifying or integrative elements in his or her life. The criterion of success is internal (psychological success), not external. In short, the protean career is shaped more by the individual than by the organization and may be redirected from time to time to meet the needs of the person.” (Hall, 1976: 201; cited in Hall and Mirvis, 1995: 271).

In this paper, the life stories of managers are analyzed from a narrative identity perspective to explore the common themes and patterns shared by these individuals on their way to accomplishing a protean career (Atkinson, 1998; Ibarra, 2003; McAdams, 1993). The interviewees describe journeys of ups and downs, successes and doubts, and most of all a process of finding out who they really are and what matters most to them in their careers. Many have found the courage to make significant changes to their careers, sometimes raising surprise and suspicion among peers; others know they have not yet reached the end of their 
journey and are planning career changes that will bring them closer to their envisioned career goals.

The findings suggest that protean identity construction occurs as an iterative cycle comprised of (1) the discovery of conflicting expectations, (2) the exploration of one's own values and capabilities, (3) the commitment to one's own path and (4) defending that path. Individuals thereby draw on various narrative practices to support each of these steps. In particular, the discovery of conflicting expectations is supported by the practices of 'questioning' and 'disenchanting'; the exploration step is facilitated by 'soul-searching', 'rebelling' and 'pushing growth'; commitment involves ‘sacrificing', ‘trusting' and 'reframing'; finally, the defense of the protean identity is enabled by 'validating', 'insuring', and 'distancing' . With these results, the article makes three important contributions: First, while the concept of a protean career and the underlying macro-environmental trends that cause shifts in career contracts have received much attention, this study contributes towards a better understanding of how individuals actually translate the concept into their work life. Second, the study develops a cyclical model to explain the narrative construction of protean identities, complementing Hall's (1996) conceptualization of the protean career as a series of lifelong learning cycles. Finally, the paper addresses calls for more whole-life perspectives on individual careers (e.g., Briscoe et al., 2006; Hall 1996; Hall and Mirvis, 1995) by exploring how protean careers are shaped over a life span, rather than over isolated career episodes.

\section{Protean careers as a response to changing work environments}

Changes in organizational environments have caused a shift away from traditional organizational careers (Arthur and Rousseau, 1996; Hall, 2002; Hassard et al., 2012; Inkson, 2006; Sennett, 1998). For managers, this implies increased vulnerabilities and insecurities about their career trajectories, causing “feelings of anxiety, insecurity, and low morale [...] given widespread organizational change, the downgrading of career prospects, and the 
erosion of societal and organizational norms about career security and 'jobs for life’” (Hassard et al., 2012: 574-575). This raises serious questions about how managers can regain a sense of control and agency as active shapers of their careers rather than falling victim to the vulnerabilities of modern organizational environments and related career insecurities (e.g., Ehrenreich, 2006; Fraher and Gabriel, 2014; Giddens, 1991; Korman et al., 1981; Sennett, 1998; Vough et al., 2015).

This study draws on the concept of protean careers as a contemporary career concept that in addition to ideas of increased career mobility places a strong emphasis on individual agency and self-direction, identity as a guiding 'compass' and personal values shaping career trajectories (Gubler et al., 2014; Hall, 2002; Inkson, 2006). While the term protean originally highlights the notion of adaptability (Inkson, 2006), further theoretical developments of the concept focus predominantly on aspects of self-direction and value-driven career management, emphasizing psychological or subjective career success over objective success measures (Feldman and Ng, 2007; Hall, 1996, 2002; Hall and Mirvis, 1995). In essence, the protean career is driven by personal values and directed by individuals rather than organizations (Briscoe et al., 2006; Hall, 2002), turning managers into designers and strategists of their own career paths.

Traditionally, the managerial career progression would mainly depend on organizational expectations and bureaucratic career structures in determining advancement regularities and restricting career choices (e.g., McKinlay, 2002; Sennett, 1998). Hall (1996, 2002) refers to the 'old psychological contract', which includes a tradition of long-term loyal relationships between employers and their managerial staff being slowly substituted by more precarious, boundaryless career structures (Arthur, 1994; Arthur and Rousseau, 1996; Hall, 1996; Hassard et al., 2012; Sennett, 1998; Stroh et al., 1994). In particular, professionals are asked to be more flexible in multiple ways. They are expected to be (a) flexible in terms of their 
skill set, continuously learning new skills and (b) flexible in terms of career changes, being willing to change jobs, employers, or even careers throughout their work life (Arthur, 2008; Feldman and Ng, 2007; Hall 1996, 2002).

Despite the discussions of the importance of the protean career in modern work environments, not every professional will automatically develop a protean identity. Hall (1996) highlights that while some individuals will embrace the freedom of protean career contracts, others may find it “terrifying” (p. 10). Many business school graduates, for example, still believe in the importance of starting their careers with widely known companies to build up their professional identity and legitimacy, benefitting from the status and reputation associated with a specific organization (e.g., Bidwell et al., 2015). The myth of the bureaucratic career model and related career scripts (Fraher and Gabriel, 2014; Jackall, 1988/2010; Stovel and Savage, 2006) remain undeniably prevalent in the thought and practices of certain individuals and organizations, resulting in challenges for managerial identity construction (Bardon et al., 2017; Harding et al., 2014; Maclean et al., 2011; Sveningsson and Alvesson, 2003).

In addition to proactive career management, conceptualizations of protean careers emphasize the reliance on subjective success measures (e.g., Feldman and Ng, 2007). As a consequence, there are two important components to a protean career: (1) As subjective success is based on personal values and preferences, individuals must be aware of those values in the first place. Therefore, the ability to recognize and reflect upon one's preferences is central to the protean career (Alvesson and Willmott, 2002; Hall, 1996; Hall et al., 2002, Hirschi et al., 2017; Marcia, 1966). (2) In addition to being aware of one’s career preferences, proteans must be able to commit to and enact their career accordingly (Feldman and Ng, 2007; Gubler et al., 2014; Hirschi et al, 2017; Marcia, 1966; Super et al., 1996). 
While the concepts of boundaryless and protean careers have received significant attention in the research over the past decades, evidence on how managers actually experience this shift in their everyday work life, and how they manage the at times conflicting definitions of a successful career, remains relatively sparse (e.g., Briscoe et al., 2006; Hall, 2002). For example, further clarification is needed on how individuals escape the pressures of old contracts and related career scripts when they conflict with individual ideas on desirable career paths and related success measures (Alvesson and Willmott, 2002; Biese, 2017; Harding et al, 2014; Peiperl and Baruch, 1997). Scholars have, therefore, repeatedly highlighted the need for a deeper understanding of career paths from more individualistic approaches (Arthur, 1994; Arthur et al., 2005; Gunz, 1989; Khapova and Arthur, 2011). In particular, narrative approaches to understanding identity processes seem promising in the exploration of the identity construction of professionals and managers (Arthur, 2008; Bardon et al., 2017; Bosley et al., 2009; Fraher and Gabriel, 2014; Hoyer and Steyaert, 2015; Ibarra, 2003; Roberts et al, 2005; Sims, 2003; Sveningsson and Alvesson, 2003). As the successful pursuit of protean careers depends on clarity about one's identity and efficacy or commitment in the implementation of personal career preferences, theories of narrative identity construction help to explain how narratives or life stories (McAdams, 1993) support the protean individual in constructing a clear vision of the self and in keeping up the high levels of motivation and resilience required to implement their protean career path (e.g., Bardon et al, 2017; Sveningsson and Alvesson, 2003). To contribute to a deeper understanding of these processes, this study sets out to investigate how managers narratively construct a protean identity over their life span and how specific narrative practices support them in shaping, implementing and defending their protean identity.

\section{Introducing a narrative identity perspective on protean careers}


Narrative approaches in the context of career studies explore how crucial turning points and career decisions are framed to cope with past or present changes and to motivate potential future changes (Fraher and Gabriel, 2014; Gabriel et al., 2010; Hoyer and Steyaert, 2015; Ibarra, 2003; Ibarra and Barbulescu, 2010; McAdams, 1993; Vough et al., 2015). In particular, this study draws on narrative identity theory as a specific narrative approach that places the focus of analysis on the stories that people create around their life trajectories (McAdams, 1993, 2011). Narrative identity is defined as “an internalized and evolving story of the self that provides a person's life with some semblance of unity, purpose, and meaning. [...] [It] combines a person's reconstruction of his or her personal past with an imagined future in order to provide a subjective historical account of one’s own development” (McAdams, 2011: 100). The narratives or stories that people tell, therefore, are a means of making sense of their unique biographies with the goal of constructing coherent stories to support their self-understanding as “goal-directed, motivated, and purposeful” (McAdams, 1993: 68). It is important to note that these life stories include memories that date back far before entering one’s work life (e.g., Fraher and Gabriel, 2014; Ibarra and Lineback, 2005) and focus on the significant life events across the whole life span that shape an individual's identity (McAdams, 1993).

Referring to the importance of recognizing an individual’s ‘career history’ (Inkson, 2002), Hall et al. (2002) highlight the challenge for protean individuals to keep the different stages of their identity connected and ensure a sense of continuity despite (career) changes - staying “true to one's career history and basic values” while embarking on a transformative career journey that is “still integrated with one’s earlier identity” (Hall et al., 2002: 160). In narrative terms, these basic values are reflected in the core thematic lines of one's life story (McAdams, 1993) that represent who a person is and what she or he aspires to in life. They 
serve as guiding principles that shape the story plot when reconstructing one's identity in light of one’s career choices and changes.

Specific narrative practices can help to frame life stories in particular ways to construct stories that remain true to the core thematic lines of the protean identity (e.g., Ibarra, 2003; Ibarra and Lineback, 2005). While versions of the stories can change over time, it is not necessarily the actual events or 'ingredients' of the story that change, but rather the selection of significant memories and how they are framed (Kegan, 1982; McAdams, 1993). Fraher and Gabriel (2014), for example, explore how stable ‘identity anchors’ such as childhood dreams (in that case, the dream of flying for pilots) influence occupational identity and the way in which individuals handle traumatic experiences such as job loss. Vough et al. (2015) illustrate that even with similar factors triggering retirement decisions, different individuals attribute different meanings to these factors. Based on individual sense-making, individuals construct a personal retirement narrative that often differs from the narrative constructed by others despite sharing similar circumstances. The authors specify six types of narratives that managers create around their transition from work life into retirement with either a stabilizing or threatening effect on their identities.

The present study further assumes that protean individuals draw on a repertoire of narrative practices or 'strategies’ (Hoyer and Steyaert, 2015) to construct their protean identities and formulate different versions of such stories throughout their career journey to integrate experiences of change into their narratives. Such continuous narrative (re)construction of one's identity has the power to facilitate transformation and help individuals to achieve their vision of who they want to be (Ibarra, 2003; McAdams, 1993, 2011; Roberts et al, 2005; Sveningsson and Alvesson, 2003).

\section{Method}


This study draws on an interpretative, narrative methodology, using life story data to explore managerial identities (e.g., Fraher and Gabriel, 2014; Maclean et al., 2011; Watson, 2009). The life story method represents a form of biographical research providing individuals with an opportunity to talk about different experiences and stages in their lives (Atkinson, 1998; Bertaux and Kohli, 1984). This methodology seems especially suitable because it captures respondents' career trajectories over a long-term view as the underlying values and beliefs that shape their work expectations and aspirations are often formed long before an individual enters work life or a specific work environment (Kish-Gephart et al., 2015; Rodrigues et al., 2013; Super et al., 1996). The life story interview method allows for the capture of such influences as it explores career histories in light of managers’ overall life trajectory, including childhood experiences, educational backgrounds and the role of parents and other key persons along their trajectories.

\section{Data collection}

Following a theoretical sampling strategy (e.g., Locke, 2001; Miles and Huberman, 1994), a total of 29 interviews were conducted with professionals at different career stages and with various backgrounds. The interviews typically lasted between 1 and 2 hours. Each interviewee had experienced at least one significant career change, and many had experienced multiple such changes including, for example, changes within corporate contexts, or dropping out of corporate contexts into academic or entrepreneurial careers (Feldman and Ng, 2007). What qualifies interviewees as 'protean' in addition to experienced career changes is their narratives focusing on taking responsibility of their trajectory based on personal values and motivations. Most of the interviewees (21 out of the 29) were in the age bracket of 30-45 representing midlife in terms of career age (Hall and Mirvis, 1995; Super, 1990) and a crucial mid-term life span often accompanied by significant changes (Gersick and Kram, 2002; Levinson and Levinson, 1996; Levinson et al., 1978). Eight interviewees were older than 45, four of which 
were turning 60 or older. A total of 16 interviewees were female, and 13 were male. Most of the interviewees (25) were European nationals (German, British, Swiss, Austrian, and Portuguese), and the remaining nationalities included Russian, South Korean, Bolivian and US American. Most of the interviewees had lived and/or worked in different countries than their native ones. The work contexts covered a variety of industries (including consumer goods, manufacturing, engineering, transportation, financial services), organizations (including large corporations, as well as smaller companies and start-ups) and functions (including marketing, corporate relations, IT, human resources) to avoid any particular industry or functional bias. The interviews were only loosely structured. Typically, a recent change in the career of the interviewee or a particular significant episode served as a conversation starter. The interviewee was then asked to trace back her or his trajectory using clarifying questions to dig deeper into individual backgrounds and personal lives and guide the interviewee through different life episodes. While the interviews were therefore conducted in a very open-ended and narrative style, a catalogue of life story interview questions based on Atkinson (1998) was used as a reference guide for (follow-up) questions. This was to ensure coverage of key topics and to move beyond descriptions of episodes toward exploring, for example, underlying values, emotions and the interviewees’ sense-making of specific episodes.

Data analysis

Data analysis proceeded in multiple stages inspired by constructivist grounded theory approaches (Charmaz, 2006; Glaser and Strauss, 1967; Locke, 2001) with data collection and analysis overlapping and including reiteration between data and theorizing from the data. A first analytical step consisted in going back to individual stories and starting to compare and contrast the stories with one another (Miles and Huberman, 1994) by re-listening to recordings, reading through transcripts and consulting interview notes. As the data collection proceeded, the interview notes first provided important clues to reoccurring themes, with a number of 'déjà 
vu' moments occurring during the interviews. An example of such moments is the explicit emphasis of multiple interviewees on the importance of having an actual impact on their work environment and the people with whom they work and linking that to career change decisions. Another example related to what was captured in the interview notes as the 'two steps forward, one step back rule' - with multiple interviewees reporting having accepted career changes that could be interpreted as a career step backwards in a traditional, objective sense, including (temporary) sacrifices in responsibilities or salaries, for example (Feldman and Ng, 2007). A more systematic coding of the interviews later added to this list of initially observed themes. With the list of initial codes created in step one, a second analytical step served to categorize the initial observations and, in particular, to distinguish between what were labelled core themes of the protean identity (Figure 1, center) and narrative practices. The core themes of protean identities (McAdams, 1993) as highlighted at the center of the conceptual model (Figure 1), summarize the codes representing more general statements about an individual's identity ( $\mathrm{am}$...), e.g., being a person who always thrives to learn something new or being a person for whom it is important to have an actual impact. Other initial codes were categorized as narrative practices, with a repertoire of such practices summarized in Table 1 after cleaning up initial overlaps and repetitions until a stable repertoire of codes was established to capture the identified practices. For example, it was striking during the interviews, and reinforced later during analysis, how often the interviewees expressed a certainty that future opportunities will arise or trusting that things will work out for them and how seemingly positively they framed even events such as past redundancies - everything seemed to be an opportunity for them. Initially, this positive outlook raised questions with regard to a potential 'accidental' sampling bias that lead to the recruitment of only persons with little hardship experiences in their lives. However, the number and variety of interviewees and the fact that most of them have not only had good experiences in their past but had also gone through periods of significant challenges 
including, for example, redundancies, suggested that such observations were indications of specific narrative practices. Related observations were categorized under the labels 'trusting' and 'reframing' (see Figure 1, g, h and Table 1).

A third analytical step was empirically as well as conceptually inspired with the aim of identifying the relationships between the different themes and narrative practices and suggesting a conceptual model to capture the researcher's interpretation of the empirical narratives (e.g., Locke, 2001: 52-54). Having identified and categorized the core themes and narrative practices, the narrative practices were now grouped according to the different functions they seem to exert in the narratives. For example, the practices of 'disenchanting' and 'questioning' fulfil the role of challenging internalized expectations and assumptions about what an ideal (managerial) career path should look like (e.g., Gersick and Kram 2002; Watson, 2009). These practices also express the self-reflection of individuals discovering the tensions between what they had previously believed about what a successful career should look like versus how they actually define a successful career based on their own values and aspirations. Grouping the practices according to common shared purposes in this way also led to the exploration of the idea of stages. The data initially suggested a potential sequential order of some narrative elements, for example, the interviewees referred to stages in their life at which they were not yet ready for a specific career change despite already recalling a desire for such change at a potential future point. This suggested that the awareness of one's own values and career goals precedes the actual implementation of corresponding changes. Being sensitized to such a potential sequential relationship triggered an exploratory process to determine the relationship among the different groups of practices in a representative conceptual model. This analytical step was furthermore conceptually inspired by related discussions of developmental stages or phases relating to identity formation processes (e.g., Erikson, 1980; Erikson and Erikson, 1997; Kegan, 1982; Levinson and Levinson, 1996; Levinson et al., 1978; Marcia, 
1966) and the idea of career stages and learning cycles in protean career studies (Gubler et al., 2014; Hall, 1996; Hall and Mirvis 1995; Super, 1990; Super et al., 1996).

Several iterations of this process of developing a model to best allow the capturing of experiences across the interviewees led to the model in Figure 1. In this process, the evolving model was constantly challenged, adjusted and refined using each interview as a case to assess how well the current model fits, and if necessary making the appropriate adaptations. For example, an earlier version of the conceptual model had not yet taken into account the abovedescribed differences between being aware of personal (career) preferences and committing to them by making career decisions accordingly and grouped together aspects of exploring and committing to a specific career path. Reiterating this initial model with the data revealed that it did not sufficiently allow for the representation of the differences among individuals who are at an exploration stage and do know what they want and envision specific career changes (e.g., wanting to become self-employed or changing jobs) but who did not yet feel ready to implement such change. As a consequence, the model was refined into a four-step model that distinguishes between step 2: 'Exploring one’s own values and capabilities' and step 3: 'Committing to one’s own path'.

A similar iterative process was used to further refine the identified narrative practices. For example, initially the category of 'exploring' also included quotes that referred to the discovery of one's own values and differences to external expectations. When further reiterating and 'testing' how well this reflected the actual interview data, a decision was made that the model did not do sufficient justice to the nuances observed in the data, and these instances were separated into distinct narrative practices labelled "questioning”, “soul-searching” and "pushing growth", the first capturing instances in which clashes among expectations were discovered and the others summarizing explorations of one’s values and skills in different jobs. 
The narrative methodology, while appropriate for the focus of this study, poses a number of challenges and limitations. For example, it is important to remember that life stories are not necessarily accurate recollections of what actually occurred in the past, but the result of what and how people remember significant life events or turning points - the importance lies in the way in which these subjective recollections and their linking with other events in our life history reflect our personal 'myths': our values, assumptions and the way in which we make sense of our life (Kegan, 1982; McAdams, 1993). Consequently, the findings presented here describe and discuss the identity narratives of the interviewees, not necessarily their actual careers. The interviewees narrate what they remember about their career trajectory and related decisions - in a way, they narratively relive their careers in their stories. While this does not allow claims to be made about the actual career experiences, it allows for the analysis of how the interviewees make sense of their past and create a coherent protean story that links past events to the present and influences the anticipated future. ${ }^{2}$

Furthermore, the interview situation itself was important in ensuring internal validity (e.g., Bosley et al., 2009). The interviewer made sure to establish an initial rapport as basis for an open conversation. During the interview, the interviewer aimed to be attentive to the reactions of the interviewee, e.g., body language, indicating comfort or discomfort, and sought to explore the interviewees' responses rather than making assumptions, e.g., further probing or providing tentative summaries "If I understand you correctly...” as a way of 'verifying' and inviting the participants to further explore or give examples. External validity (e.g., Bosley et al., 2009) was mainly ensured by comparing and contrasting the findings with other related studies, e.g., checking consistency with established identity and career theories. Consistency was found, for example, in the observation of the role of self-exploration. However, additional aspects were identified in this study that seemed to have been less explored previously, e.g., the narrative 
practices of defending the protean identity with only few studies mentioning this aspect on a more general basis (e.g., Alvesson and Willmott, 2002; Sims, 2003).

\section{Findings}

This chapter introduces a conceptual model that maps out the different elements of the narratives upon which the interviewees draw when reflecting upon important career changes and their overall career trajectory. The model explains the narrative construction of protean identities as individuals create a story of how they have discovered their own values and goals and how they have entered a self-directed career path aligned with these values and goals. Narrating career changes and reflecting upon their decision-making process, the story plot of the individuals typically contains steps reconstructing how they discovered alternative options to traditional career patterns and expectations, clarifying which options are most aligned with their own values, interests and capabilities and finding the courage to act upon these preferences, for example, by making significant career changes. The conceptual model and the related narrative practices are summarized in Figure 1 and Table 1.

$$
\text { --- Insert Figure 1, Table } 1 \text { here --- }
$$

A coherent protean life story underlying the protean identity expresses the different experiences, decisions and phases of an individual's (work) life in such a way that they align with their core values and signal a sense of agency. The data suggest a number of commonly shared values among the interviewees expressed through recurring core themes (McAdams, 1993). These themes describe the observed key features of a protean identity (Figure 1, center) such as 'Hard work gets rewarded', 'I am in control', 'I am confident in what I want and what I am good at', 'I want to make a difference' and 'Never stop learning'. In their stories, the individuals draw on a repertoire of narrative practices to frame how they came to discover the core aspects of their identity, how specific career decisions were encouraged and legitimized, and how they defend their identity and specific choices against 
challenges by others or against self-doubts (Alvesson and Willmott, 2002; Ibarra and Deshpande, 2007; Sims, 2003). These narrative practices are, therefore, central to developing a coherent story line and are intertwined with the core themes representing protean values. For example, the narrative practice of 'sacrificing' (Figure 1, f) is based on the core theme of 'hard work gets rewarded' (Figure 1, center) and the belief that working hard in life includes periods of sacrifice and compromise to achieve future goals. Such narrative practices therefore fulfil the role of enacting the core themes in the overall story plot; they are used to link these core themes to the actual decisions and actions that are described in the story. The following paragraphs describe each of the four identified core building blocks of the protean story plot and the role of the identified narrative practices.

\section{(1) Discovering conflict in expectations}

The first building block in this model 'Discovering conflict in expectations' (Figure 1, 1) describes the parts of the narratives in which the individuals recollect moments of awakening or becoming aware of one's own values in contrast to often conflicting expectations in the institutional environment including family, educational institutions, or typical career paths reinforced through the media and other forms of public discourse (e.g., Watson, 2009). While the interviewees may recall several such moments of clashes throughout their work life, they are often first experienced much earlier in childhood, adolescence or early adulthood. For example, Kiran recalls a moment in his school life when he realizes that the chosen school and typically associated career path with its education (typically, graduates go into apprenticeships in financial services) is not what he really wants for himself:

"I thought hard about it and I looked at the people around me in my class and thought 'I don't fit here' [...] they all had no plan, they did not want more, [...] And I thought 'what are you doing?' You start some kind of apprenticeship, you will be the oldest, and afterwards you will end up in some kind of administrative job” (Kiran, interview 18) 
When confronted with conflicting expectations, individuals become consciously aware of clashes between the expectations that are imposed upon them and their own ideas and expectations for their future (work) life. Individuals realize that there are alternative (career) options available and that career paths can take multiple forms - for example, they do not have to study law or become a teacher just because of family tradition or parental expectations. As a consequence, they recall 'questioning' why they have pursued certain interests or paths and whether the decisions they have made really reflect their own preferences. They challenge taken-for-granted assumptions and external expectations with regard to one's career options, for example, the realization that they have been copying or blindly following pre-established paths without much consideration or reflection on how this path aligns with personal preferences, as illustrated by the following quote:

"I did a Business Studies degree and in the final year I had to specialize and I chose accountancy. But then one day I took one look at my dad [who was an accountant] and thought 'no!' (laughs) And I changed it [...] I did Business because I wanted to generally go in that direction that my dad had gone into. It never really at the time occurred to me to go down a [different] route.” (Bruce, interview 22)

This narrative practice is often complemented by the practice of 'disenchanting,' which questions rewards, success measures or other career aspects that one had previously enjoyed and perceived as valuable and desirable, especially if the conflicts are experienced once an individual has already pursued a certain path such as a corporate career for a few years. For example, a number of the interviewed managers have experienced career phases during which they genuinely enjoyed extrinsic rewards such as company cars as externally visible symbols of their career success or other life-style and status benefits associated with a more typical 
career path that focuses on objective success measures (Feldman and Ng, 2007). Becoming aware of how these elements now contradict what they identify as core values of their identity and what they are actually looking for in their career, they re-assess these aspects, attributing much less importance to them than previously (Biese, 2017; Gersick and Kram, 2002; Levinson and Levinson, 1996; Levinson et al., 1978; Super, 1990): “I was sick of driving company cars”. In their narratives, the interviewees construct a picture of such rewards as having lost their charm or desirability as they realize how these symbols of success are inherently interlinked with the externally imposed ideals of the career patterns that they discard. Often, related narratives refer to changes in life circumstances or entering a different stage of one's life that triggers the change in priorities.

"I worked in sales and business development and in marketing, I really enjoyed it and it was very glamorous in many ways you know, nice cars, nice hotels, nice events, nice whatever.

[...] However, I literally just realized at some point that it was great and I loved it but after a while it was, well, it was enough and I felt that I wanted to wake up every day feeling that what I was doing really had a purpose.” (Meryl, interview 12)

(2) Exploring one's own values and capabilities

While increasing awareness of conflicts between external expectations and personal preferences is at the heart of the first building block of the protean story plot, the second block is characterized by acting upon the experienced conflict and actively exploring what an individual is actually good at doing (can do) and wants to do: "I think I can do this and I think I'd enjoy this".

The practice of 'soul-searching' captures recollections of how to discover what brings enjoyment to an individual and includes both aspects of reflection and experimentation with different jobs and work contexts to explore which contexts correspond best to who an 
individual wants to become (McAdams, 1993; Super, 1990; Super et al., 1996). Soulsearching facilitates considering one’s own interests - diverting from seemingly prescribed paths and going along with what others do or expect one to do and, instead, considering what one truly wants. Such experimentation often involves narratives of 'rebelling' by breaking with imposed expectations and traditions (e.g., family traditions, traditional corporate career progressions) and pursuing different options, for example, by deliberately deciding against parental expectations and advice on study choices or career moves. John (interview 6), for example, was promoted into a position at his employer's headquarters after working his way upwards in one of the divisions of a large multinational corporation. The step up to headquarters was his stepping stone up the corporate ladder, reaching the heights of top management was just a question of time. However, while everyone expected him to embrace this opportunity, he decided to leave the corporate function again a couple of years later to move back into the division - a step backwards on the corporate ladder but back into his comfort zone and aligning with what he truly enjoys doing, where he felt he could focus on what matters to him such as having a true impact and working with people who share similar values. By doing so, a person actively breaks expectations and violates taken-for-granted assumptions on what the 'right' thing to do would be. Such disruptions of expectations become visible in reactions from surrounding persons who may be irritated by the choices taken by managers:

"I left after a few months even though I should have gotten my promotion to executive level there. [My colleagues asked:] 'Are you stupid? You will miss out on your promotion?' and I said: 'Yes, because I can't work with these people and I can't stand behind what I am doing. "” (Mike, interview 27) 
Furthermore, the core theme of 'never stop learning' at the heart of protean values is represented in the strategy of 'pushing growth' in the form of constantly challenging oneself, improving on existing skills and acquiring new skills. As a narrative practice, 'pushing growth' refers to the observation that when explaining specific career choices and changes in their stories, the interviewees frequently phrased such decisions as opportunities for learning and personal growth. The interviewees thereby repeatedly emphasized how they have been proactively pushing personal boundaries, for example, when trying out things that they did not necessarily previously define as their core strength:

“Previously, I was always a good student without any effort, so I could do any subject without a problem. At [this school] I saw my limits and I think it was good somehow. [...] [Later,] at university I gave myself another chance with Mathematics and I took calculus. And I think that's the biggest value: that everything was challenging." (Katie, interview 14)

This exploration of one's capabilities and preferences serves as much as a means of learning what an individual enjoys and for which he or she has talent as it is about defining boundaries by identifying the things that they do not enjoy or do not feel excelling at. Pushing growth as a mode of continuous self-challenging involves taking charge of one's own (learning) journey and owning one's choices, which is closely linked to the core theme of agency as the perception of being in control of one's own path.

(3) Committing to one's own path

This third element is linked to the courage of actually implementing career decisions that result from the preceding self-exploration practices. Such commitment might demand some significant career changes that go beyond the changes an individual has pursued as part of the exploration and experimentation described in the practices of the second building block. Inevitably, there are some overlaps between the two - for example, commitment to one's own 
career path is likely to continue the theme of seeking continuous opportunities for development and growth. However, this third building block accounts for the observation that while references to exploring different work options and experimenting, learning and reflecting upon one's preferences were prominent in all of the interviewees' stories, some interviewees revealed that while envisioning corresponding career changes, they still have not yet realized this step. Others had made such significant career changes to live a more protean work life at the time of the interview but recalled periods in their prior work life when they already knew what they wanted to do; however, they lacked the commitment to pursue that final step and actually initiate the change. In this regard, a number of interviewees told stories about aspiring to work self-employed or become entrepreneurs as their ultimate goal of living a career according to their protean preferences; yet, they had not yet done so. These narratives were fed by reasons related to the need for financial security and providing for families, or not feeling ready because they told themselves they (still) lacked the right level of skill or experience, for example, for a successful entrepreneurial venture. Therefore, further inspired by differentiation of self-exploration and commitment or implementation (Marcia, 1966; Super et al., 1996) or identity clarity and self-efficacy (e.g., Hirschi et al, 2017) as two key aspects of protean careers - exposing a protean career orientation and actually taking a protean career path (Gubler et al., 2014) - this observation was captured by separating these two elements of (a) gaining clarity about one's values and capabilities and then (b) having the courage to make career decisions in accordance with these preferences.

Thus, what are the narrative practices used by the interviewees to build a coherent story around why a particular point in life was right to initiate change, while they had previously been hesitant to commit to more radical changes? The strategy of "reframing” serves individuals to re-interpret the challenges along their path that might have previously held them back. Aspects of an anticipated career change that they perceived as not truly fitting 
with the previous versions of their story (because that is not really who they are or what they want) are reframed in a way that they become part of a coherent story - in the spirit of 'yes, I did not like that before, but my perspective has now changed'. For example, for Susan, one of the core advantages of her previous career in professional services and without a family to care for was the flexibility in deciding her work time pattern and being able to work whenever and wherever she wanted. This would have been a key factor in working according to her values and preferences. As she made the decision to change careers into a large corporate multinational that might not deliver the same flexibility (and also becoming a mother shortly after) the idea of being more constrained in time is now reframed as a source of "inspiration" in her story:

“Today, I am working exactly 8.25 hours every day because it is impossible to manage with childcare otherwise. I need to squeeze work into this time window. That was a big challenge in the beginning but by now it is also kind of an inspiration because it is forcing me to do things in a certain time.” (Susan, interview 5)

'Sacrificing' is a further key practice, for example, when individuals recollect deliberately accepting career moves that could be characterized as backwards moves considering a more typical career progression. This could, for example, relate to corporate career trajectories, because a particular move means regressing in hierarchical terms and/or losing associated privileges including cuts in salary or responsibility. Such sacrifices are often portrayed as only temporary, meaning that they will last for a transitionary period and are necessary to implement a career transition (for example, re-training to be prepared for a new career). They are framed as temporary sacrifices or compromises with an expected delayed reward and link back to the core theme of 'hard work gets rewarded' - reinforcing the belief that these sacrifices will indeed pay off and are therefore the right thing to do. 
One reoccurring pattern across interviews was a type of faith or trust displayed by the interviewees of being in control of their own future or that things will turn out well for them. For example, many were certain that whatever occurs in the future, including risks such as redundancy, they would be able to find appropriate work again. It seems that this firm belief in being able to successfully handle whatever situation might occur in their future work life provides a feeling of confidence and trust that is necessary to continue on their self-chosen path, independent of risks or failures along the way. This practice of 'trusting', therefore, is an important narrative practice to reassure individuals on their path as a basis for remaining persistent and patient, even during challenging times, and to mitigate some of their (previous) fears of making a significant career change. The interviewees reinforce this belief by using expression such as being absolutely certain or absolutely convinced. In the following quote, Yvette recalls how 'weird' it felt that once she changed her career to pursue truly 'interesting' and 'fascinating' work, she found a new confidence that this is a career that would work out over the long term, independent of the potential drawbacks that she might have to face:

“I don't think I ever had a situation where I was finishing [one job] without having signed for the next. This is the first time I have this thing, and it is fantastic. I know where I am going [...] I haven't signed but I don't worry about it, and that is a very weird place to be."

(Yvette, interview 29)

\section{(4) Defending one's own path}

This last component, labelled 'defending one’s own path,' might sound surprising in light of defining a protean career as one that is based on personal values, interests and capabilities and caters towards subjective individual success measures. What is there to defend, and against what or whom? Considering that the protean journey as described thus far demands the individual to actively combat external career expectations and objective career success 
factors, and given the described career 'sacrifices' from a more objective or traditional career view point (Feldman and Ng, 2007; Watson, 2009) as well as the risks associated with taking alternative paths, it might seem less surprising that the interviewees build defense strategies into their career stories that help them handle personal doubts and/or challenges that come from their social environment. Step four in the model, therefore, emphasizes the narrative practices used by individuals to stabilize, legitimize and defend their protean story. The practice of 'validating' relates to the construction of a sense of everything coming together and finding one's true protean identity, combining the different puzzle pieces from one’s past history. Being able to make significant career changes necessitates the discovery of that which aligns with the protean vision of oneself as well as the identification of that which does not match and has been found to be less essential to one's identity. Once they decided to commit to a significant change in career with all of the attached risks, the interviewees seek reassurance by linking this current choice to past choices, childhood dreams, or core values it makes sense because this is what I always wanted or who I always was (e.g., Fraher and Gabriel, 2014; Super et al., 1996). Such validation or reassurance supports the decision and reinforces the conviction of having made the right choice. Meryl, for example, decided to leave a large financial services institution for a smaller microfinancing agency and 'validated' this decision as follows:

"I was always driven by helping people [...] I didn't have that helping people element [in the previous jobs] and here I was 'oh it's business but it's helping people', it's doing some sort of good. So that's why I was always attracted to microfinance, sustainability, something like that.” (Meryl, interview 12)

The narrative practice of 'insuring' is about having some back-up plan if things go wrong, and it includes access to sufficient resources to mitigate the risks associated with a career change, including financial resources which, interestingly, are often accumulated as a result 
of having previously successfully pursued a more conventional career path (e.g., corporate careers with a hierarchical progression). Alison, for example, was only able to pursue a drastic career change leaving her well-paid job in professional services due to the financial cushion she had built up: "I had enough money to support myself during [the career change] and afterwards even if I needed, so I felt relaxed on that part.” (Alison, interview 1)

Insuring further includes building back-up options into career change narratives; in the extreme, the assurance of even being able to go back to the 'old' career, having built up the networks, and a certain status in case a person realizes at some point that a career change does not work out as planned. Susan (interview 5), for example, justifies her career change to a new business area from a fast-track management career back to a client-based operational career in two ways: (1) this change allowed her to do what she wanted and (2) it also allowed her to accumulate a new skill set that would be valued whatever future direction she decides to take, thus leaving all options open to return back to the management track at later stages. Finally, ‘distancing' represents another practice as means of defending the choices made and stabilizing the protean identity. Distancing involves comparing the current self and the pursuit of a protean career path to alternative options, other people pursuing these options or even former versions of oneself. It captures the notion of being different and 'this is not me', creating a narrative around more typical careers and the people pursuing them as violating one's own values and positioning oneself in clear opposition:

"When I think back to recruitment events where former graduates come that have been [with well-known consultancies] for a few years now and talked about their journey, I just thought that these are incredibly boring people [...] They had made plans about what internships to pursue to be best able to enter consulting as fast as possible and then, after a few years, change the company and then later get a position with one of the former corporate clients. I 
am sure they had great careers and they earned good money and I hope they were happy with their choices. However, I found these people incredibly boring.” (Danny, interview 11)

In some instances, distancing would involve an additional strong normative or even moral judgement of the comparison of the protean self to, for example, others who are conforming to societal expectations, elevating one's own morals and values above those of the 'others':

"I am a very honest person who wants to be able to face clients in the long-term and sell them something useful. I have experienced otherwise in the industry with people just caring for themselves. Clients’ benefits did not count much." (Kiran, interview 18)

In sum, these narrative practices provide endorsement of career choices, discarding external expectations and pre-scribed career paths. They offer reassurance that one's sacrifices have been worthwhile and contribute towards stabilizing the protean career orientation.

From an analytical perspective, the proposed conceptual model suggests a sequential order of the four identified building blocks, in line with underlying life cycle theories of identity formation and career development as discussed above in the data analysis section. The career narratives resonate with such a sequential logic as the chronology of the stories places moments of discovering clashes in self-identity and external expectations before a process of exploration and personal growth through various career stages. Many of the interviewees also make deliberate distinctions among the moments in their life when they recall having discovered what they really want from their career but where they had not yet had the opportunity or been courageous enough to actually implement the necessary changes. However, other elements in the model can overlap between different phases. For example, the practice of validating served individuals to signal reassurance in their stories that they have made the right choice after a change had occurred; though, it was equally used when 
reconstructing moments of decision-making before actually implementing a change. Another example is illustrated above when highlighting that practices such as, for example, 'pushing growth,' extend beyond the second stage to which they are primarily allocated. Therefore, while there is an underlying sequential logic to the components in the model from a conceptual viewpoint, the actual stories rarely make such clear-cut stage-related distinctions, and the conceptual building blocks and related practices can overlap in a specific narrative. Furthermore, the proposed model of narrative protean identity construction is intended to represent a general pattern of the elements of protean life stories. However, personal differences and nuances apply as to (a) how many of these 'loops' can be included in the overall story or how many sub-stories an interviewee tells referring to particular career episodes (Hall, 2002) and (b) how intensely they experience each step. For example, similar to the idea of recycling through different career stages, or multiple career episodes as repeating learning cycles (e.g. Hall, 1996, 2002; Hall and Mirvis, 1995; Super et al., 1996), some stories comprised several (full or partial) loops of the cycle of building blocks. For example, Connor (interview 15) describes a major transformation from a corporate marketing and sales career to the nonprofit sector as part of his story and recalls that at this time in his career he felt he had arrived in a context that was considerably more suited for him (e.g., the experience of a true family like community). He then continues his story that a few years later he realized that this was just an intermediate step followed by another major transformation embarking on an academic career - his story line therefore includes two loops of the model, with each narrative for his first and second major transition making use of the four building blocks and related practices: having discovered clashes between the previous work context and what he is actually looking for, discovering what really suits him and what he is capable of, committing to a major change and defending his choice. Similar, Charlie (interview 2) describes her transformation from a corporate career to becoming a self-employed consultant. When asked about her future vision, 
surprisingly, she starts discussing plans for another envisioned transformation and talks about cracks appearing in her former ideal about how she would feel in her self-employed role. While much of her story up to this point had framed self-employment as a relief from the downsides of her previous corporate career and a liberation from bureaucratic structures and clashes with her own values (therefore closing a first loop of the model in her narrative), anticipating how her story might continue in the future, she begins to elaborate on how new clashes in expectations and reality appear, and she imagines potential future careers, for example, as an academic (opening another loop of the model in her story). Therefore, an overall life story could include several sub-stories or narratives that relate to specific career episodes (Gubler et al., 2014; Hall and Mirvis, 1995; McAdams, 1993), drawing on the identified building blocks and related practices in each of these sub-stories.

\section{Discussion}

In response to increasing career vulnerabilities faced by managers today, this study set out to investigate how people construct a protean identity as a basis for a self-directed career that is aligned with personal values and subjective definitions of career success. A protean career identity offers a way to cope with the multiple challenges, frustrations and anxieties to which managers are exposed as a consequence of changing societal and organizational contexts (Accenture, 2007; Giddens, 1991; Hales, 2002; Hall, 2002; Hassard et al., 2012; Prins et al., 2015; Sims, 2003; Watson, 1994/2001). In particular, the study draws on narrative identity theory (McAdams, 1993, 2011) and the understanding that individuals use their personally constructed life stories as a means of understanding who they are, framing their past, present and anticipated future into a meaningful story that provides purpose and direction. These personal narratives or stories support managers in shaping, implementing and defending a career path in line with their self-identity. 
The findings suggest a conceptual model that explains how individuals narratively construct their protean identity through story plots that incorporate four core building blocks: (1) the discovery of conflicting expectations, (2) the exploration of one's own values and capabilities, (3) the commitment to one’s own path and (4) defending this path. Individuals thereby draw on various narrative practices to support each step, in particular, the discovery of conflicting expectations is supported by the practices of 'questioning' and 'disenchanting'; the exploration step is facilitated by 'soul-searching', 'rebelling' and 'pushing growth'; commitment to one's own path involves 'sacrificing', 'trusting' and 'reframing'; finally, the defense of the protean identity is enabled by 'validating', 'insuring', and 'distancing'. These findings make three important contributions. First, while the concept of a protean career and the underlying macro-environmental trends that cause shifts in career contracts have received much attention, this study contributes towards a better understanding of how individuals actually translate the concept into their work life. In particular, the study provides further clarification of the link between identity and career changes (Arthur, 2008, Hall et al., 2002). Constant career changes are a typical component of protean careers and can be interpreted as threatening identity stability. This raises questions with regard to the proteans' ability to protect their identity and remain true to themselves in the context of continuous change (Hall et al., 2002). The concept of narrative identity allows individuals to cope with change with a continuously evolving narrative (e.g., Ibarra and Barbulescu, 2010). This evolving story allows individuals to make sense of their life and (re)frame a coherent story, incorporating changes, to stabilize and validate their sense of self (McAdams, 2011). For managers, this sense-making allows them to construct a narrative identity that explains how they see themselves in their organizational contexts and how they address potential conflicts between institutional expectations and internal preferences (Bardon et al., 2017; Giddens, 1991; Harding et al, 2014; Super, 1990; Sveningsson and Alvesson, 2003; Watson, 2009) by 
creating a story that best corresponds to their core values and beliefs and that best closes the gap between who a person aspires to be and who she or he believes to be at present. Second, the study develops a cyclical model that explains the narrative construction of protean identities and that complements Hall's (1996) conceptualization of the protean career as a series of lifelong learning cycles. The generated insights on the link between narrative identity construction and career change reinforce the idea of approaching a protean identity not as a binary variable (being a protean or not) but rather as a process, or journey (Ashforth, 1998; Sveningsson and Alvesson, 2003; Super et al., 1996). Becoming a protean is a life-long achievement supported by the narrative sense-making of the past, present and anticipated future in the stories that people create about their personal journey.

While previous studies have identified a number of components or stages of protean careers (such as self-exploration, self-reflection, self-efficacy) (e.g., Hall, 2002; Hirschi et al., 2017; Super, 1990; Super et al. 1996), the current study expands these findings by taking a narrative identity lens and identifying and categorizing the different elements of the protean identity from this perspective, as well as organizing these elements into a process model to highlight how they work in interaction and complement one another. The proposed model of narrative identity construction as an iterative cycle of discovering, exploring, committing and defending further expands our understanding of the link between the continuous stages or learning cycles in a protean career and individual identity (Arthur, 2008; Gubler et al., 2014; Hall et al., 2002; Super et al., 1996) and reiterates the nature of the protean career and identity development as a result of "many cycles of learning stages (continuous learning), rather than a single lifelong career stage cycle” (Hall and Mirvis, 1995: 269). While some of the identified elements relate to previous studies on career development stages (e.g., aspects of exploration), previous research seems to particularly neglect the element of defense of the protean identity. Protean managers as reflective individuals seek constant 
reassurance in pursuing the right choices - this is facilitated by the narrative practices of 'validating', 'insuring' and 'distancing' that have been discussed in the findings. Specifically, the strategy of 'distancing' was surprisingly strong, at times even taking on the nature of demonizing by adding a strong normative judgement to alternative career options. An example of this is the elevation of the protean self above people who pursue alternative options or organizations that support more traditional organizational contracts in the sense of 'I am more ethical' or morally higher in values. These insights further expand the limited evidence on how individuals defend their identities (e.g., Alvesson and Willmott, 2002) and specifically on the influence of 'reference groups' that exercise pressure (Grote and Hall, 2013; see also Bosley et al., 2009; Watson, 2009).

Other identified practices such as 'questioning' are linked to defense strategies as the moments of discovering compliance with external expectations, such as following in the family footsteps with occupational choices (Grote and Hall, 2013). Hall and Mirvis (1995) make reference to examples of such moments of realization experienced by managers when they actively reflect on their past choices and decisions, for example, while engaging in career planning exercises. What seems less explored is the consequences of such questioning and distancing, especially when it takes on a stronger form of demonizing including strong moral judgements and thereby inevitably burning bridges between the reconcilability of traditional organizational contracts and protean careers. This raises a number of challenges, especially for managers pursuing a corporate career, as it is likely that they will need to balance the organizational pressures that are often still linked to the idea of more traditional career contracts with their own protean values (Bardon et al., 2017; Sims, 2003). These insights also highlight that while following a protean career can be rewarding and fulfilling, there is a dark side to it in the form of constant challenges to this self-centered career 
approach against more traditional organizational contracts and career success definitions that still shape corporate culture in many organizations today (e.g., Jackall, 1988/2010). Third, the paper addresses calls for more whole-life perspectives on individual careers to consider the influences of the social context outside work boundaries (e.g., Briscoe et al., 2006: 31; Grote and Hall, 2013; Hall 1996; Hall and Mirvis, 1995). With the life story approach (Atkinson, 1998; McAdams, 1993), the study thus addresses the often neglected link between protean careers and individual career histories (Inkson, 2002) and follows a call for research methods that account for the rich life histories beyond the actual work context that influence career development (e.g., Arthur, 2008; Fraher and Gabriel, 2014; Khapova and Arthur, 2011; Super et al., 1996; Watson, 2009). Some of the identified narrative practices, for example, 'validating', represent attempts to link one’s past, present and future, e.g., by linking early childhood experiences to present career decisions (see also Fraher and Gabriel, 2014). Other practices establish this link more indirectly as the repeated cycle of narrative identity construction starts before an individual enters work life, and each repetition of the cycle across the whole life span intensifies or further stabilizes the protean identity. As with all research, the particular focus and method of this study exhibits limitations. First, as with all constructivist grounded theory approaches, limitations apply with regard to the proposed theory or explanatory model and related interpretations and choices made by the researcher (Charmaz, 2006: chapter 6; Locke, 2001: 52-54). For example, while this study identifies a number of narrative practices that support the construction of protean identities and integrates them into a conceptual model, it by no means claims that this is an exhaustive or conclusive list. Future research is invited to further refine and contribute to the existing list of narrative practices and strategies (e.g., Hoyer and Steyaert, 2015) and further validate the underlying mechanisms of narrative identity construction served by these practices. 
Second, due to the nature of this study and the focus on professionals and managerial careers, the generalizability of the findings is limited. Many of the interviewees who shared their stories for this research project were not only well-educated and highly skilled but they also fit into the pattern of career studies that focus on Western, industrialized contexts and are often based on very particular samples that are limited in diversity (e.g., Baruch et al., 2015; Briscoe et al., 2012). Indeed, the narrative identity construction cycle discussed in this study might be much more applicable to white-collar workers and professionals with more academic backgrounds, for example, benefitting from transferable skills that facilitate career changes. Equally, many of the interviewees were in a fortunate position of not having to worry about existential financial insecurities, and many had safety nets in place (financial, or in terms of networks) to cushion career changes if needed. This does not demean the significance of the changes they implemented during their careers or undermine the courage needed to enact a protean identity; however, it does somewhat limit the transferability of the findings to individuals who fall outside these boundaries.

\section{Conclusion}

When people look back on their career and life histories at a particular point in time, they construct a narrative that (ideally) provides a coherent story of who they are and why they are where they are today (McAdams, 1993). This article explored the career stories of professionals who pursue managerial careers in corporate contexts or have decided to drop out of corporate careers. The study analyzed the stories of these managers entering the corporate world, their journey within as well as their way out of corporate careers. The typical building blocks of these stories were identified as well as the related narrative practices that drive the narrative construction of what is labelled 'protean identities' following protean careers (Hall 2002). In their stories, the interviewees reconstructed their career trajectories, identifying why they have made certain career decisions or how they have 
coped with situations in which the decision was out of their hands (e.g., redundancies). With the help of specific narrative practices, they formulate a coherent story to make sense of their past trajectory, their present situation and their anticipated and envisioned future. The narrative practices identified in this paper fulfil various functions from encouraging (future) moves to defending past decisions and protecting self-identity. Taken together, the practices represent an important tool in creating a story line that emphasizes agency and a sense that individuals are directing their careers, rather than victimizing and feeling exposed to the vulnerabilities of modern-day corporate work environments (e.g., Fraher and Gabriel, 2014; Hassard et al., 2012; Korman et al., 1981; Sennett, 1998; Vough et al., 2015). This sense of agency lies at the heart of a protean identity - authoring a story around a self-directed, valuedriven identity that allows one to cope with the pitfalls of modern managerial careers and to find meaning in navigating the obstacles and contradictions of corporate managerial careers or finding alternative career paths (Gubler et al., 20014; Hall, 1996, 2002).

\section{Acknowledgements}

I would like to express my sincere gratitude to all interviewees that were willing to share their stories with me. I would also like to thank the editorial team and three anonymous reviewers for their constructive feedback and guidance throughout the review process. Furthermore, Linda Rouleau and her team at HEC Montréal, Laure Cabantous and Annamari Tuori have provided invaluable feedback on previous versions of the manuscript. Finally, I would like to acknowledge the financial support received by the British Academy.

\section{Funding}

This research was supported by funding from the British Academy/ Leverhulme Small Research Grants program (grant number: SG143365). 


\section{Notes}

${ }^{1}$ All names referring to study participants are pseudonyms to respect anonymity.

${ }^{2}$ I thank Reviewer 2 for the constructive comments on how to approach the difference between actual career experiences and narratives about these experiences, strengthening the focus of the analysis. 


\section{References}

Accenture (2007) Middle Managers Around the World Unsatisfied with Their Organizations, Accenture Survey Finds. Available at: https://newsroom.accenture.com/subjects/talentorganization-performance/middle-managers-around-world-unsatisfied-with-theirorganizations-accenture-survey-finds.htm.

Alvesson M and Willmott H (2002) Identity regulation as organizational control: Producing the appropriate individual. Journal of Management Studies 39(5): 619-44.

Arthur MB (1994) The boundaryless career: A new perspective for organizational inquiry. Journal of Organizational Behavior 15: 295-306.

Arthur MB (2008) Examining contemporary careers: A call for interdisciplinary inquiry, Human Relations 61(2): 163-186.

Arthur MB and Rousseau DM (eds) (1996) The Boundaryless Career: A New Employment Principle for a New Organizational Era. New York: Oxford University Press.

Arthur MB, Khapova SN and Wilderom CPM (2005) Career success in a boundaryless career world. Journal of Organizational Behavior 26: 177-202.

Ashforth BE (1998) Epilogue: What have we learned, and where do we go from here? In: Whetten D, Godfrey P (eds) Identity in Organizations. London: Sage, 269-271.

Atkinson R (1998) The life story interview. Qualitative Research Series 44. Thousand Oaks: Sage.

Bardon T, Brown AD and Peze S (2017) Identity regulation, identity work and phronesis. Human Relations 70(8): 940-965.

Baruch Y, Szücs N and Gunz HP (2015) Career studies in search of theory: the rise and rise of concepts. Career Development International 20 (1): 3-20.

Bertaux D and Kohli M (1984) The life story approach: A continental view. Annual Review of Sociology 10: 215-237. 
Bidwell M, Won S, Barbulescu R and Mollick E (2015) I used to work at Goldman Sachs! How firms benefit from organizational status in the market for human capital. Strategic Management Journal 36: 1164-1173.

Biese I (2017) Opting Out and In: On Women's Careers and New Lifestyles. New York: Routledge.

Bosley SLC, Arnold J, Cohen L (2009) How other people shape our careers: a typology drawn from career narratives. Human Relations 62(10): 1487-1520.

Briscoe JP, Hall DT, Frautschy DeMuth RL (2006) Protean and boundaryless careers: An empirical exploration. Journal of Vocational Behavior 69: 30-47.

Briscoe JP, Hall DT and Mayrhofer W (eds.) (2012) Careers around the World. Individual and Contextual Perspectives. New York: Routledge.

Charmaz K (2006) Constructing Grounded Theory: A Practical Guide through Qualitative Analysis. London: Sage.

Ehrenreich B (2006) Bait and Switch. The Futile Pursuit of the Corporate Dream. London: Granta Books.

Erikson EH (1980) Identity and the Life Cycle. New York: WW Norton and Co.

Erikson EH and Erikson JM (1997) The Life Cycle Completed. New York: WW Norton and Co.

Feldman DC and Ng TWH (2007) Careers: Mobility, embeddedness, and success. Journal of Management 33(3): 350-377.

Fraher AL and Gabriel Y (2014) Dreaming of flying when grounded: Occupational identity and occupational fantasies of furloughed airline pilots. Journal of Management Studies 51(6): 926-951.

Gabriel Y, Gray DE and Goregaokar, H (2010) Temporary derailment or the end of the line? Managers coping with unemployment at 50. Organization Studies 31(12): 1687-1712. 
Gersick CJG and Kram KE (2002) High-achieving women at midlife: An exploratory study. Journal of Management Inquiry 11(2): 104-127.

Giddens A (1991) Modernity and self-Identity: Self and Society in the Late Modern Age. Cambridge: Polity Press.

Glaser BG and Strauss AL (1967) The Discovery of Grounded Theory: Strategies for Qualitative Research. Chicago: Aldine.

Grote G and Hall DT (2013) Reference groups: A missing link in career studies. Journal of Vocational Behavior 83: 265-279.

Gubler M, Arnold J and Coombs C (2014) Reassessing the protean career concept: Empirical findings, conceptual components, and measurement. Journal of Organizational Behavior 35: S23-S40.

Gunz H (1989) The dual meaning of managerial careers: Organizational and individual levels of analysis. Journal of Management Studies 26(3): 225-250.

Hales C (2002) 'Bureaucracy-lite' and continuities in managerial work. British Journal of Management 13: 51-66.

Hall DT (1976) Careers in Organizations. Glenview, IL: Scott, Foresman and Company. Hall DT (1996) Protean careers of the 21st century. Academy of Management Executive 10(4): 8-16.

Hall DT (2002) Careers In and Out of Organizations. Thousand Oaks, CA: Sage.

Hall DT and Mirvis PH (1995) The New Career Contract: Developing the whole person at midlife and beyond. Journal of Vocational Behavior 47: 269-289.

Hall DT, Zhu G and Yan A (2002) Career creativity as protean identity transformation. In: Peiperl MA, Arthur MB and Anand N (eds) Career creativity: Explorations in the Remaking of Work. Oxford: Oxford University Press, 159-79. 
Harding N, Lee H and Ford J (2014) Who is 'the middle manager'? Human Relations 67(10): $1213-1237$.

Hassard J, Morris J and McCann L (2012) ‘My brilliant career’? New organizational forms and changing managerial careers in Japan, the UK, and USA. Journal of Management Studies 49(3): 571-99.

Hirschi A, Jaensch, VK and Herrmann A (2017) Protean career orientation, vocational identity, and self-efficacy: An empirical clarification of their relationship. European Journal of Work and Organizational Psychology 26(2): 208-220.

Hoyer P and Steyaert C (2015) Narrative identity construction in times of career change: Taking note of unconscious desires. Human Relations 68(12): 1837-1863.

Ibarra H (2003) Working Identity: Unconventional Strategies for Reinventing your Career. Boston, MA: Harvard Business School Press.

Ibarra H and Barbulescu R (2010) Identity as narrative: Prevalence, effectiveness, and consequences of narrative identity work in macro work role transitions. Academy of Management Review 35(1): 135-154.

Ibarra H and Deshpande PH (2007) Networks and identities: Reciprocal influences on career processes and outcomes. In: Gunz Hand Peiperl M (eds) Handbook of Career Studies. Los Angeles, CA: SAGE, 268-82.

Ibarra H and Lineback K (2005) What's your story? Harvard Business Review 83(1): 65-71. Inkson K (2002) Thinking creatively about careers: The use of metaphor. In: Peiperl M, Arthur MB and Anand N (eds) Career creativity: Explorations in the remaking of work. Oxford: Oxford University Press, 15-34.

Inkson K (2006) Understanding Careers: The Metaphors of Working Lives. Thousand Oaks, CA: Sage. 
Jackall R (2010) Moral Mazes. The World of Corporate Managers. Twentieth Anniversary

Edition. Oxford: Oxford University Press. (originally, Oxford University Press 1988)

Kegan R (1982) The Evolving Self: Problems and Process in Human Development. Cambridge, MA: Harvard University Press.

Khapova SN and Arthur MB (2011) Interdisciplinary approaches to contemporary career studies. Human Relations 64(1): 3-17.

Kish-Gephart JJ and Campbell JT (2015) You don’t forget your roots: The influence of CEO social class background on strategic risk taking. Academy of Management Journal 58(6): 1614-1636.

Korman AK, Wittig-Berman U and Lang D (1981) Career success and personal failure: Alienation in professionals and managers. Academy of Management Journal 24(2): 342360.

Levinson DJ and Levinson JD (1996) Seasons of a Woman's Life. New York, NY: Alfred A. Knopf.

Levinson DJ, Darrow CN, Klein EB, Levinson M and McKee B (1978) Seasons of a Man's Life. New York: Random House.

Locke K (2001) Grounded Theory in Management Research. London: Sage Publications.

McAdams DP (1993) The Stories We Live by: Personal Myths and the Making of the Self. New York: Guilford Press.

McAdams DP (2011) Narrative identity. In: Schwartz SJ, Luyckx K and Vignoles VL (eds) Handbook of Identity Theory and Research. New York: Springer, 99-115.

McKinlay A (2002) 'Dead selves': The birth of the modern career. Organization 9(4): 595614.

Maclean M, Harvey C. and Chia R (2011) Sensemaking, storytelling and the legitimization of elite business careers. Human Relations 65(1): 17-40. 
Marcia JE (1966) Development and validation of ego-identity status. Journal of Personality and Social Psychology 3(5): 551-558.

Miles MB and Huberman AM (1994) Qualitative Data Analysis (2 ${ }^{\text {nd }}$ edn). Sage: Thousand Oaks.

Mollick E (2012) People and process, suits and innovators: The role of individuals in firm performance. Strategic Management Journal 33: 1001-1015.

Peiperl M and Baruch Y (1997) Back to square zero: The post-corporate career. Organizational Dynamics 25(4): 7-22.

Prins SJ, Bates LM, Keyes KM, and Muntaner C (2015) Anxious? Depressed? You might be suffering from capitalism: Contradictory class locations and the prevalence of depression and anxiety in the USA. Sociology of Health \& Illness 37(8): 1352-1372.

Roberts LM, Dutton JE, Spreitzer GM, Heaphy ED and Quinn RE (2005) Composing the reflected best-self portrait: Building pathways for becoming extraordinary in work organizations. Academy of Management Review 30(4): 712-736.

Rodrigues R, Guest D and Budjanovcanin A (2013) From anchors to orientations: Towards a contemporary theory of career preferences. Journal of Vocational Behavior 83: 142-152.

Sennett R (1998) The Corrosion of Character: The Personal Consequences of Work in the New Capitalism. New York: Norton.

Sims D (2003) Between the millstones: A narrative account of the vulnerability of middle managers’ storying. Human Relations 56(10): 1195-1211.

Stovel K and Savage M (2006) Mergers and mobility: Organizational growth and the origins of career migration at Lloyds Bank. American Journal of Sociology 111(4): 1080-1121.

Stroh LK, Brett JM and Reilly AH (1994) A decade of change: Managers' attachment to their organizations and their jobs. Human Resource Management 33: 531-548. 
Super DE (1990) A life-span, life-space approach to career development. In: Brown D, Brooks L and Associates (eds) Career Choice and Development ( $2^{\text {nd }}$ edn). San Francisco: JosseyBass, 197-261.

Super DE, Savickas ML and Super CM (1996) The life-span, life-space approach to careers. In: Brown D, Brooks L and Associates (eds) Career choice and development ( $3^{\text {rd }}$ edn). San Francisco: Jossey-Bass, 121-178.

Sveningsson S and Alvesson M (2003) Managing managerial identities: Organizational fragmentation, discourse and identity struggle. Human Relations 56(10): 1163-1193.

Vough HC, Bataille CD, Noh SC, and Lee MD (2015) Going off script: How managers make sense of the ending of their careers. Journal of Management Studies 52(3): 414-440.

Watson TJ (2001) In Search of Management (revised edition) London: South-Western Cengage Learning (originally, Routledge 1994).

Watson TJ (2009) Narrative, life story and manager identity: A case study in autobiographical identity work. Human Relations 62(3), 425-52.

Wooldridge B, Schmid T and Floyd SW (2008) The middle management perspective on strategy process: Contributions, synthesis, and future research. Journal of Management 34, $1190-1221$. 
Table 1. Narrative practices supporting the narrative construction of protean identities

\begin{tabular}{|c|c|c|}
\hline $\begin{array}{l}\text { Narrative } \\
\text { practices }\end{array}$ & Explanation & Exemplar quotes \\
\hline Questioning & $\begin{array}{l}\text { Becoming aware of and } \\
\text { challenging conformity with } \\
\text { taken-for-granted assumptions } \\
\text { and externally imposed } \\
\text { expectation }\end{array}$ & $\begin{array}{l}\text { "I did have an identity crisis at one point and I was like what am I? I don't fit into this } \\
\text { and this." (interview 3) } \\
\text { "I think there are some people [...] they finish business school and they say 'I want to be } \\
\text { the next [director of a particular function at a well-known corporation]'. I didn't have } \\
\text { such a goal, a target in mind. I very much think about what is right for me now, what are } \\
\text { the skills I need and where do I want to go now and the next step." (interview 12) }\end{array}$ \\
\hline Disenchanting & $\begin{array}{l}\text { Constructing rationales for shifts } \\
\text { in values and priorities; } \\
\text { reassessing success and rewards }\end{array}$ & $\begin{array}{l}\text { "I've done all that [fly around in executive jets and go to expensive restaurants, travel } \\
\text { the world, be with top executives] and I'm not very interested. You can only eat so many } \\
\text { steaks at fancy restaurants in five star luxury hotels, you know what I mean, it gets } \\
\text { boring." (interview 9) } \\
\text { "Interestingly, I turned fifty ... and I thought: do I really need to do this? Do I need to? } \\
\text { [...] It was quite satisfying just being a parent, and I didn't feel the same need within } \\
\text { myself to have that status." (interview 22) }\end{array}$ \\
\hline Soul-searching & $\begin{array}{l}\text { Reflecting upon and discovering } \\
\text { one's own values and interests as } \\
\text { opposed to imposed external } \\
\text { expectations }\end{array}$ & $\begin{array}{l}\text { "[And I thought] no, I don't even want to go that way. Do you want to get higher up [the } \\
\text { career ladder] or do you want to enjoy. The search for meaning became more important } \\
\text { than the value of that career." (interview 6) } \\
\text { "They just offered me the typical open positions. That was an additional eye-opener for } \\
\text { me: 'what do I actually want in life?' Is it really these options or do I not have much } \\
\text { more potential, and what are alternative options." (interview 16) }\end{array}$ \\
\hline Rebelling & $\begin{array}{l}\text { Deliberately breaking with the } \\
\text { traditions and imposed external } \\
\text { expectations }\end{array}$ & $\begin{array}{l}\text { "My engineering studies were a form of rebellion at the age of 18, because this was } \\
\text { unheard of in my family."(interview 5) } \\
\text { "At first, I think [my parents] did not support my decision [...] They were like 'why are } \\
\text { you doing [this]?' You have a good career, you like what you're doing." (interview 3) }\end{array}$ \\
\hline $\begin{array}{l}\text { Pushing } \\
\text { growth }\end{array}$ & $\begin{array}{l}\text { Challenging oneself; exploring } \\
\text { ways to strengthen skills and } \\
\text { acquire new skills; testing and } \\
\text { pushing personal boundaries }\end{array}$ & $\begin{array}{l}\text { "Nobody spoke English, so I had to learn fast. Well, actually in about six weeks because } \\
\text { I was spending } 24 / 7 \text { in an environment where nobody spoke English. So if you want a } \\
\text { cup of tea or some food, you've got to speak in their language." (interview 9) } \\
\text { "In sales you need to be extroverted, open, and I did not know if I can be that but I } \\
\text { needed to test it out to know for sure." (interview 18) }\end{array}$ \\
\hline
\end{tabular}




\begin{tabular}{|c|c|c|}
\hline Sacrificing & $\begin{array}{l}\text { Accepting downsides of career } \\
\text { decisions such as downward } \\
\text { moves or missing out on } \\
\text { promotions for potential delayed } \\
\text { benefits (e.g., by learning new } \\
\text { skills) }\end{array}$ & $\begin{array}{l}\text { "And even though I was frustrated, three years is a very solid time to sit in that job and } \\
\text { learn and put your head down and shut up and work and work and work. And that's what } \\
\text { I did." (interview 12) } \\
\text { "When I [left], I was among the top } 100 \text { people in a large company. And I left } \\
\text { voluntarily, not even having messed up. I was in my mid 50s and went into a context } \\
\text { where the second oldest colleague was in his 30s. Many people said 'he is completely } \\
\text { crazy." (interview 19) }\end{array}$ \\
\hline Trusting & $\begin{array}{l}\text { Believing that opportunities will } \\
\text { arise in the future }\end{array}$ & $\begin{array}{l}\text { “No, I am not afraid. I would always find a new job. And I also don't have any fears in } \\
\text { case I would only find one that pays less. I don't have any existential fears." (interview } \\
\text { 27) } \\
\text { "I never thought it's not going to work. I always thought I have to work hard." } \\
\text { (interview 14) }\end{array}$ \\
\hline Reframing & $\begin{array}{l}\text { Re-interpreting seemingly } \\
\text { negative turns as opportunities; } \\
\text { re-framing in a more optimistic } \\
\text { narrative; emphasizing the } \\
\text { positive aspects when confronted } \\
\text { with challenges }\end{array}$ & $\begin{array}{l}\text { "I even considered my layoff a victory, because I kept my chin up. I always acted } \\
\text { according to my values and never changed them. And I never tried to be someone else." } \\
\text { (interview 18) } \\
\text { "I had to go one step back in the career ladder. However, actually, it should have been } \\
\text { two steps according to the organizational structure and the skills I brought. However, } \\
\text { the company acknowledged that this is an investment for both sides and we met in the } \\
\text { middle." (interview 5) }\end{array}$ \\
\hline Validating & $\begin{array}{l}\text { This makes sense because others } \\
\text { have (always) seen it in me; } \\
\text { I have always been a certain way }\end{array}$ & $\begin{array}{l}\text { (leaving a long corporate career for academia) "What I always used to enjoy was } \\
\text { understanding why something occurred the way it did. Therefore, I did not want to know } \\
\text { the result, I wanted to understand why that worked, how it worked and how you could } \\
\text { change it and so on. In addition, I'd also obviously been structured in my thinking ... I } \\
\text { don't know, maybe I did my jobs in a pseudo-academic way because I had to have shape } \\
\text { to it, I had to have structure and I had to understand you know, context and all that sort } \\
\text { of stuff. [...] And [my partner] said to me, well, just go and do it because clearly you fit." } \\
\text { (interview 15) }\end{array}$ \\
\hline Insuring & $\begin{array}{l}\text { Having a back-up plan, often } \\
\text { including skills or resources } \\
\text { from previous careers or } \\
\text { financial reserves to cushion a } \\
\text { career change }\end{array}$ & $\begin{array}{l}\text { "We always ensured to have a high degree of financial freedom. There was no house to } \\
\text { be paid, no mortgage to worry about. It was absolutely clear that we would be able to } \\
\text { survive on dramatically less money. We had sufficient reserves to cover a couple of } \\
\text { years." (interview 8) }\end{array}$ \\
\hline
\end{tabular}




\begin{tabular}{|l|l|l|}
\hline & & $\begin{array}{l}\text { “And that's why it was so important to me to go to school because I thought okay, I don't } \\
\text { know what I'm getting into but at the end of the day if this doesn't work out, I walk away } \\
\text { with my business degree and I can do something with that. And so that was very } \\
\text { calculated in my mind to make sure that I didn't fall too hard." (interview 12) }\end{array}$ \\
\hline Distancing & $\begin{array}{l}\text { Setting oneself apart from others } \\
\text { and the values commonly } \\
\text { attributed to more typical career } \\
\text { paths }\end{array}$ & $\begin{array}{l}\text { respect for the guy. He did very well in his career and it didn't surprise me at all." } \\
\text { (interview 22) } \\
\text { "When I see my former colleagues today, how they hang in there, stressed out, hoping } \\
\text { that the next promotion will come eventually, I am thinking 'poor crazy guys'. I am so } \\
\text { happy my life looks different today. The term 'career' has changed its meaning for me." } \\
\text { (interview 5) }\end{array}$ \\
\hline
\end{tabular}




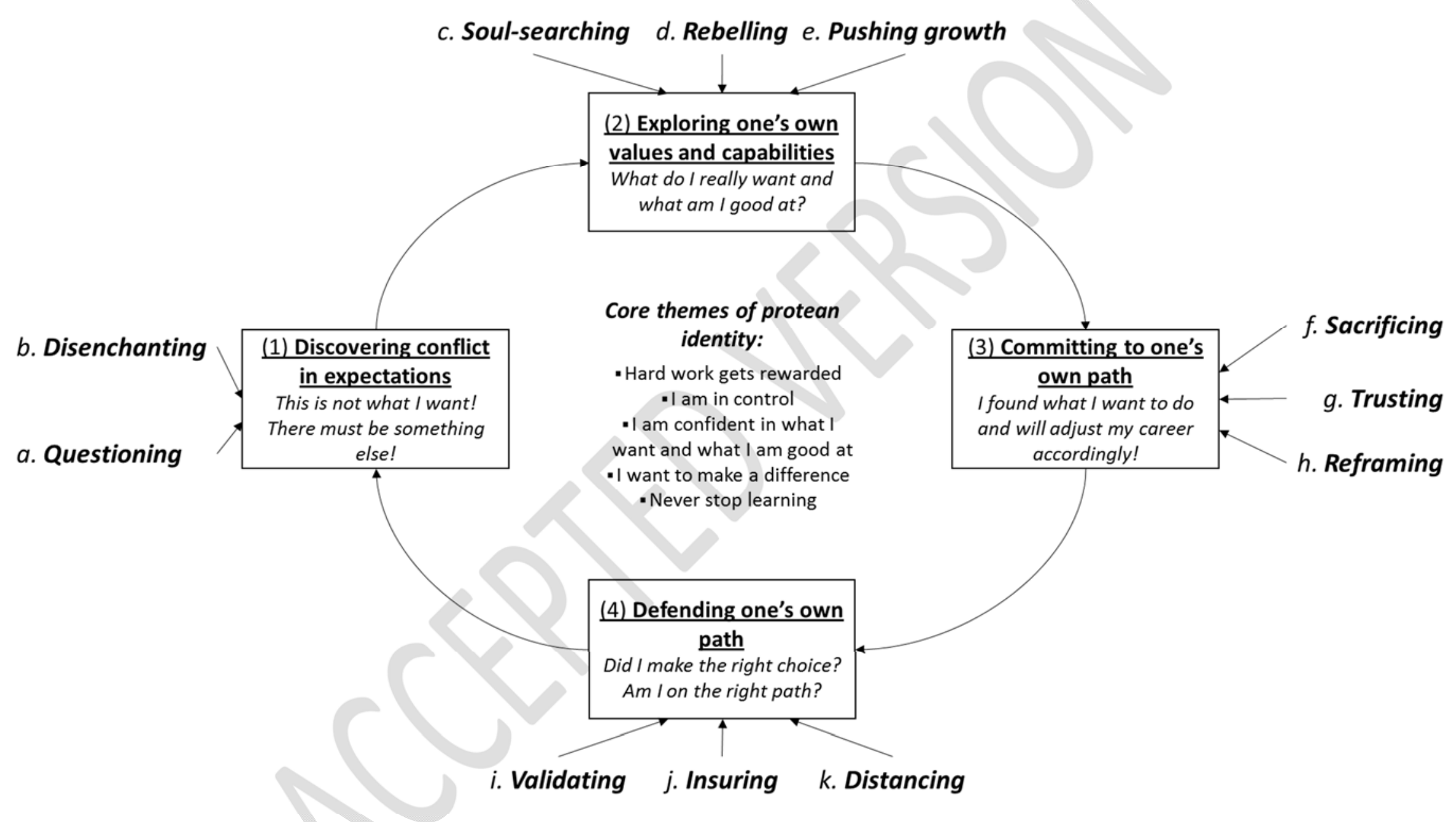

Figure 1. A conceptual model of the narrative construction of protean identities. 
Carola Wolf is a Lecturer in Strategy at Aston Business School, Aston University, UK. She received her $\mathrm{PhD}$ from the University of St. Gallen, Switzerland studying the role of middle managers in strategic planning processes. Carola’s research applies a sociological perspective on strategy processes and practices, exploring issues of strategic change and the emergence of strategy in different organizational contexts. Being particularly interested in the perspective of middle managers, Carola is also focusing on management career studies, for example exploring career trajectories of middle managers. [c.wolf@aston.ac.uk]

\section{Corresponding Author:}

Carola Wolf

Aston University

Birmingham

B4 7ET

UK 